\title{
DIMENSIONS OF SOUL IN THE QURAN: AN ISLAMIC PSYCHOLOGICAL PERSPECTIVE
}

\author{
Idi Warsah \\ State Islamic Institute Curup \\ Curup Utara, Rejang Lebong, Bengkulu, Indonesia, 39119 \\ E-mail:idiwarsah@gmail.com
}

\begin{tabular}{c|c|c}
\hline Received: & Revised: & Approved: \\
$22 / 04 / 2020$ & $16 / 11 / 2020$ & $25 / 11 / 2020$ \\
\hline
\end{tabular}

DOI: https://doi.org/10.32332/akademika.v25i2.2029

\section{(a) (1) (2)}

Dimensions Of Soul In The Quran: An Islamic Psychological Perspective Licensed Under a Creative Commons Attribution-ShareAlike 4.0 International License

\begin{abstract}
Western theories tend to view the essence of humans in a way of a blank state (tabula rasa), wherein their development will be affected by environmental factors as the determinant variable. However, there are a few differences in the portrayal of humans if scrutinized from al-Qur'an. With conducting a library study, the present study sought to scrutinize the essence of humans along with the affiliated dimensions according to the Qur'anic perspective. The current study drew a conclusion that humans are composed of physical (with the overall physical power therein), psychological, and spiritual dimensions. Humans were born with their inborn good trait alongside the naturally inherent elements such as soul and the active as well as responsive supports from environments so that the two elements as such will construct humans' behavior. Even though environments will not entirely construct humans' behavior as commonly targeted by education, the inborn potencies cannot develop automatically without being simultaneously promoted by good and conducive environments in addition to effective education. The foregoing is due to the responsive trait of humans.
\end{abstract}

Keywords: Dimensions of Soul, the Potency of Ruhaniah, the Potency of Nafsiyah, the Potency of Jismiyah

\section{A. Introduction}

The Qur'an provides not only information about the oneness of Allah but also scientific information including the phenomena of humans from various dimensions. When the discussion of humans begins with the process 
, Vol. 25, No. 02 Juli - Desember 2020

of their creation, it cannot be denied that humans begin with a drop of semen which is despicable as well as weak and end with the birth of the best creatures, ones whose bodies have the potential to love, yearn, feel, think, and react. Also, they are equipped with souls that can discuss, reveal, and overcome things to be resolved. ${ }^{1}$

The Qur'ān ${ }^{2}$ oftentimes describes that the degree of humans can be raised and can also be lowered. Humans are the best creatures compared to other creatures of Allah both in heaven and on earth, likewise if compared to angels. On the other hand, humans at some point can also be described as nothing more than the cursed demons. ${ }^{3}$ The foregoing happens because humans are not only given perfect and beautiful physiques, they are also given reasons to think, fitrah to worship Allah, and desire to achieve their goals. All of those variables can also be referred to as humanistic potential. ${ }^{4}$ With such potencies, humans are valued as the creatures that can cultivate the nature. However, it is stated in Murtadha Motahhari ${ }^{5}$, they can also suddenly change drastically into the figure of "the lowest of all", due to their powerlessness to make use of their potencies in accordance with the essence of the creation of them. Therefore, their attitudes and fates are determined by themselves.

Komaruddin Hidayat said that the spiritual element is the most basic nature of human beings. ${ }^{6}$ The Qur'ân explains that basically the human spiritual element is holy and good because it is created from a good origin as well. The divine spirit was breathed by Allah into the human body, and with this divine spirit, humans are able to make a connection with Allah. In this regard, it is clear that the connection between humans and Allah is a spiritual relationship which is physically manifested in the form of worship.

The problem in the form of different perspectives on human essence is found if the Qur'anic perspective as discussed above is compared with the psychological viewpoint. In the psychological theory, Sigmund Freud in his theory said that all the driving energy in humans comes from a life instinct known as libido, which means that all actions done by humans are strongly influenced by high sexual desires. Including the origin of religion, according to Sigmund Freud in M. Quraish Syihab, religious behavior in humans is

${ }^{1}$ Abdul Hamid Dayyab and Ahmad Qarqauz, Penomena Temuan Medis: Dalam Kajian Al-Qur'ān (Jakarta: Restu Ilahi, 2004).

2 See, QS. At-Tin: 4-5 dan Al-Isra': 70

3 See, QS. Al-A'raf: 179

4 Roswati Nurdin, "Manusia dalam Sorotan Al-Qur'an (Suatu Tinjauan Tafsir Maudhui)," Tahkim 9, no. 1 (2013): 155-171. Abdul Kodir and Wawan Sonjaya, "Human Nature Based on Al- Qur'an as the Basic of Education Development", 1, no. 3 (2015): 1-26. Dudung Abdullah, "Konsep Manusia dalam Al-Qur'an (Telaah Kritis Tentang Makna dan Eksistensi)," Al Daulah: Jurnal Hukum Pidana dan Ketatanegaraan 6, no. 2 (2017): 331-44.

5 Murtadha Muthahhari, Perspektif Al-Qur'än Tentang Manusia dan Agama (Bandung: Mizan, 1992).

${ }^{6}$ Komaruddin Hidayat, Agama Di Tengah Kemelut (Jakarta: Mediacita, 2001). 
determined by sexual libido. The psychoanalytic conceptor said that:

The seeds of religion come from the "Oedipus complex" in the process of human growth and development. There is a sexual urge in the mother, and in the end the child kills the father because the father is an obstacle to the creation of that goal. But, the murder caused regret in the child's soul so that worshiping the father's spirit was born.7

Freud's opinion above illustrates that humans are born empty and do not bring with them any potential. Subsequently, in further processes, humans find the seeds of religion because of their sexual urges and experiences. This opinion confirms that human behavior will develop through the experiences obtained from the surrounding environment. ${ }^{8}$ This view is aligned with Jhon Lucke's opinion known as the "Tabula Rasa Theory" which has been supported by several other psychologists. ${ }^{9}$ According to Lucke in Muhibbin Syah, humans are born like a piece of white paper. It is the environment that shapes them and then colors them with various cultures as their frameworks of living. This means that humans are passive in accepting something that comes from outside, including matters related to science and religion. ${ }^{10}$ The environment becomes a determining factor for human development ${ }^{11}$ which actually starts from a neutral condition. ${ }^{12}$

In Lucke's perspective, religion is special and very personal, the source is "my soul and it is impossible for someone who gives instructions to me if my own soul does not give these instructions to me". ${ }^{13}$ This view is called the law of "Empiricism". Contrary to Lucke's theory, the law of "nativism" 2007).

7 M. Quraish Syihab, Membumikan Al-Qur'ān, Edisi Baru (Bandung: Mizan,

${ }^{8}$ Hamed Khosravi, "Geopolitics of Tabula Rasa: Persian Garden and the Idea of City," Journal of Architecture and Urbanism 38, no. 1 (2014): 39-53. John H. Riker, "What Do Humans Need to Be Human? Self Psychology and the Problem of Social Justice," International Journal of Psychoanalytic Self Psychology 10, no. 3 (2015): 192-204.

${ }^{9}$ Robert C. Rowland, "Tabula Rasa: The Relevance of Debate to Argumentation Theory," Argumentation and Advocacy 21, no. 2 (1984): 76-88. Koichi Togashi and Amanda Kottler, "The Many Faces of Twinship: From the Psychology of the Self to the Psychology of Being Human," International Journal of Psychoanalytic Self Psychology 7, no. 3 (2012): 331-51. Jiř́ Wiedermann, "The Computational Limits to the Cognitive Power of the Neuroidal Tabula Rasa," Journal of Experimental \& Theoretical Artificial Intelligence 15, no. 3 (2016): 267-79.

10 Muhibbin Syah, Psikologi Pendidikan dengan Pendekatan Baru (Bandung: Remaja Rosdakarya, 2008).

${ }^{11}$ Idi Warsah and others, "Muslim Minority in Yogyakarta: Between Social Relationship and Religious Motivation," Qudus International Journal of Islamic Studies 7, no. 2 (2019): 1-32.

12 Aaron Bunch, "Beyond Tabula Rasa," Argumentation and Advocacy 30, no. 3 (1994): 174-81. Teresa Freire, "Leisure and Positive Psychology: Contributions to Optimal Human Functioning," The Journal of Positive Psychology (2018): 1-4.

${ }^{13}$ Syihab, Membumikan Al-Qur'ān, Edisi Baru. 
postulated by Schoopenhour elucidated that the development of the human personality is determined by inborn factors, talents, and natural factors. In the educational term, this theory is called "pedagogical pessimism."14 Then, a Western psychologist named William Stern tried to take the middle path from his two predecessors by combining the two concepts mentioned above. His concept is known as the law of convergence. This concept argued that the innate and the environment work together in shaping human behavior. ${ }^{15}$

In the psychological discourse, experts tend to agree to accept the concept that the determinants of human personality and behavior are the physical, psychological, and environmental conditions. These three things are known as organo biology, psycho-education, and socioculturalism, and they are widely used as the basic concepts for psychiatrists and psychologists. However, the foregoing does not take into account the spiritual element as depicted in the Qur'anic perspective. The viewpoint of psychological theories tends to only view that spirituality is associated with mere subjective perceptions.

The difference in perspectives between the Qur'an and psychological theories as regards humans drives the researcher to conduct a library study on the human psychological dimensions in the Qur'anic perspective as the main basis for Islamic psychological thinking.

\section{B. Qur'anic views of Human Psychological Dimensions}

In the introduction above, it is stated that what is the most essential in humans is immaterial matter or spirit. The human mind includes lust, mind, spirit, and heart. According to Mulyana Kertanegara as cited in Sudirman Tebba, the scholars have several opinions regarding the human mind; Some explain that the soul is a mediator between the body and spirit. Without the existence of the soul, the spirit cannot rule the body. Meanwhile, the heart is between spirit and soul. Humans basically consist of body and spirit, but essence is associated with spirit, while the body only acts as the real medium in the real world. When the body is separated from the spirit (death), in this case what is dead is the body, while the spirit will continue to exist in the Barzah realm.

The potential for immateriality is hidden in humans. In the Qur'an, the term potential is represented by several words such as: ruh (spirit), al-'aql (reason), nafs (soul) al-qalb (heart) al-fuad (heart), and fitrah which must be realized in the real life through an educational process, so that it can be held accountable in the afterlife. ${ }^{16}$ In the meantime, al-Ghazali uses four terms to

14 Ngalim Purwanto, Psikologi Pendidikan (Bandung: Remaja Rosdakarya, 1999).

15 Aaron Bunch, "Beyond Tabula Rasa," Argumentation and Advocacy 30, no. 3 (1994): 174-81. Teresa Freire, "Leisure and Positive Psychology: Contributions to Optimal Human Functioning," The Journal of Positive Psychology (2018): 1-4.

16 Idi Warsah, "Interkoneksi Pemikiran Al-Ghazāli dan Sigmund Freud Tentang Potensi Manusia," Kontekstualita: Jurnal Penelitian Sosial Dan Keagamaan 33, no. 1 (2017): 54-77. 
represent the human soul, namely: 1). Ruh (spirit), 'Aql (reason), Nafs (soul), and Qalb (heart). ${ }^{17}$ Allah gave those elements of potential to humans so that humans are different from other creatures. As explained above, humans were created from the ground 18 and Divine Spirit through a process that is not described in detail. The following will describe the elements of human potential in sequence one by one.

\section{Fițrah}

When viewed from the etymological aspect, fitrah derives from the word fatr which means hemisphere of the earth, and this is where the conceptual meaning emerges, "creation or event". Apart from that, it is also understood that fatr is part of Allah's khalq (creation). Human nature is an event from the beginning or it can also be associated with congenital nature.

The word fatara is also a word that represents the creation of nature, consisting of the letters $f a^{\prime}-t \bar{a}^{\prime}-r \bar{a}$ which means fathu syai'in wa ibräzuh (opening something and showing it). An Arabic expression, such as fataran-nabāt, is meant to refer to plants that grow in a way that opens the soil in which they grow. Opening also means starting something or alibtida 'wal-ikhtirā (which refers to the meaning of starting something new) which is also commonly called 'creating or making'. This word in the form of sulāsi is found in fifteen places in the Qur'àn, including the word fitrah contained in the QS. Al-Rūm [30]: 30. The term al-fitrah is a special term from the Qur'an which refers to the basic creation as defined by the Egyptian Arabic Language Institute: A1-Khilqatul-lati yakūnu 'alaihā kullu mawjūdin awwala khalqih (The basic creation of every existence). In using the term fatara in humans, the Qur'an relates it to the creation of religion (ad-din). This implies that the term refers to the material dimension as well as the spiritual dimension of humans. ${ }^{19}$

The Qur'an emphasizes that in man there is a tendency towards goodness (faith) and rejection of evil. Allah has not only placed human nature into the faith of the Almighty and bestowed on the ability to know God, but has also created in it a natural impulse of goodness and rejection of bad deeds, sins, and actions that degrade human dignity. Therefore, unconsciously the human soul tends toward good and does not like evil iniquity. ${ }^{20}$

17 Al-Ghazāli, Ihya' Ulum Ad-Din, Jilid. III (Surabaya: Dar an-Nasyr alMishriyyah).

18 Hassan El-Ramady and others, "Soils and Human Creation in the Holy Quran: From Point of View of Soil Science," Environment, Biodiversity and Soil Security (2019) 1-9.

19 Munzir Hitami, Revolusi Sejarah Manusia: Peran Rasul Sebagai Agen Perubahan (Yogyakarta: LkiS, 2009).

${ }^{20}$ Abu Sangkan, Berguru Kepada Allah, Cet. X (Jakarta: Yayasan Shalat Khusu', 2008). 
, Vol. 25, No. 02 Juli - Desember 2020

The word fitrah, in the Qur'an is repeated twenty-eight times in various forms, fourteen of them in the context of the description of the earth and sky. The rest is in the context of human creation both in terms of acknowledging that the creator is Allah, and in terms of the description of human nature. This description of human nature is found once in surah Ar-Rūm (30): 30;

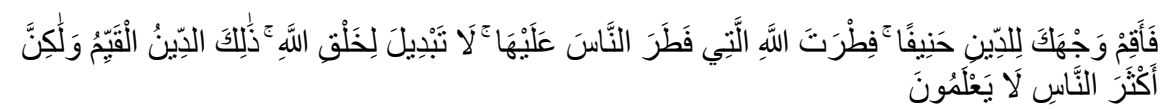

(O Prophet and his followers), turn your face singlemindedly to the true Faith and adhere to the true nature on which Allah has created human beings. The mould fashioned by Allah cannot be altered. That is the True, Straight Faith, although most people do not know. (Ar-Rüm (30): 30)

Referring to the meaning of fitrah as stated in the above verse, it can be drawn that humans from their origins bring with them the potential of true religion, and the scholars understand it as monotheism. If the word la is understood in this verse as "no," it means that one cannot avoid that quality. In the context of this verse, it is emphasized that the religious nature will remain in man forever even though it may be ignored. But, is the nature of human fitrah only limited to the nature of religion? It is certainly not. There are still other verses that talk about the creation of human potential even though they do not use the word fitrah, one of which is Surah Ali Imran (3): 14; ${ }^{21}$

M. Quraish Shihab emphasized the meaning of fitrah in his thinking. The word can be understood in terms of the origin of events or innate. The word in this verse is referred to as the condition of creation as it is implied by the continuation of this verse which states "who created man over him"22 The scholars' views regarding the word fitrah in the above verse (Qur'an 30:30) are quite diverse. Some argue that the attribute in question is the belief in the oneness of Allah that $\mathrm{He}$ has instilled in every human being. In this context, the scholars reinforce it with a hadith which states that: "All children who are born are born naturally, and then both parents make it Judaism, Christianity, or Magi." This hadith gives a message to the environment to maintain good faith and mindset because it will affect children's thoughts and behavior since they are vulnerable to be influenced.

Al-Biqā'i as cited in M. Quraish Shihab does not limit the meaning of fitrah to the belief in the oneness of Allah. According to him, what is meant by fitrah is the initial nature that Allah created as a

${ }^{21}$ M. Quraish Syihab, Wawasan Al-Qur'ān: Tafsir Tematik Atas Pelbagai Persoalan Umat, Edisi Baru (Bandung: Mizan, 2007).

${ }^{22}$ M. Quraish Syihab, Tafsir Al-Misbah: Pesan, Kesan Dan Keserasian Al-Qur'ān, V (Jakarta: Lentera Hati, 2006), XI. 
human. ${ }^{23} \mathrm{He}$ then quotes from al-Ghazali in Ihyā 'Ulüm ad-Din that "Every human being has been created on the basis of faith in Allah even at the potential to identify problems. The foregoing is naturally included in human beings as they have the potential for knowledge." Al-Biqā'i then explained that what al-Ghazali meant was the ease of obeying (Allah's orders) and the dignity of character which is a representation of Islamic nature (fitrah). This view was shown by alBiqai through the observation of children. In his writings, it is said that they have righteous behavior and are easy to obey instructions. They are not the same as adults. Thus, what is meant by fitrah is the acceptance of truth and stability in that acceptance.

It is different from Quraish Shihab in describing the meaning of fitrah. According to him, fitrah is an element and system that Allah gives to every creature. Human fitrah is what Allah created for humans, which consists of a body, mind, and soul. ${ }^{24}$ Drawing conclusions by connecting premises is fitrah in the aspect of intellectuality. On the other hand, drawing conclusions on contradictory premises does not include human fitrah. Ensuring that what the eyes see as things is associated with an intellectual fitrah, while denying it as sophisms assume is contrary to the intellectual fitrah. Then, this scholar quoted Ibn Sinā who illustrated the meaning of fitrah as follows: if a human being is born into this world in a state of perfect intellect, but he never hears a single opinion, does not believe in one school, does not associate with society or know certain tactics. He just witnesses things on a sensory basis, and he takes a number of conditions and exposes them to his mind and then tries to doubt them. In such a way, when he doubts, it means that fitrah does not support him. However, if he does not doubt, it is an indication of fitrah. However - continued Ibn Sina - not everything that is guided by human fitrah is true. What is true is only what is produced by the potential of intellect, while the fitrah of thought in general may not be true. ${ }^{25}$

Furthermore, the above verse also equates fitrah with religion, namely Islam, as understood from the continuation of the verse which says 'It is a straight religion'. There are differences in opinions from the scholars regarding the meaning of this verse. If this statement is connected with the previous statement that Allah created humans for their fitrah, then this means that Islam contains the teachings that are aligned with human fitrah. ${ }^{26}$ Therefore, it can be understood that humans have their own fitrah which guides them to a certain path in life which sees a clear goal to follow (if they want to gain happiness, and that is a special way for them). That is also indicated by the word of

${ }^{23}$ M. Quraish Shihab, Tafsir al-Misbah..... 54

${ }^{24}$ M. Quraish Shihab, Tafsir al-Misbah.... 55

${ }^{25}$ M. Quraish Shihab, Tafsir al-Misbah

${ }^{26}$ M. Quraish Shihab, Tafsir al-Misbah.....56 
, Vol. 25, No. 02 Juli - Desember 2020

God: "The fitrah of Allah who created mankind."

With their fitrah, humans can know what is lawful and forbidden (haram), right and wrong, good and bad, and noble and reprehensible. Wābishah bin Ma'bad said:

"One day, I met the Prophet. He asked, 'You came to ask about goodness?' I answered, 'it is true.' So, the Messenger of Allah said, 'Ask yourself! Kindness is something that is felt calm by the heart and soul. Meanwhile, sin is something that disturbs the heart and creates doubts in the chest." 27

Humans have a tendency to do good things and find peace of mind with their nature. If they do something despicable, then their feelings will be disturbed and agitated. They also don't want other people to know about it. On the other hand, their soul will feel safe when praise is given to them. They will not expect to receive criticism. This type of fitrah will continue to grow through good education and will weaken if humans do not receive a good education. This is as illustrated in QS. Ash-Shams, 91: 7-10;

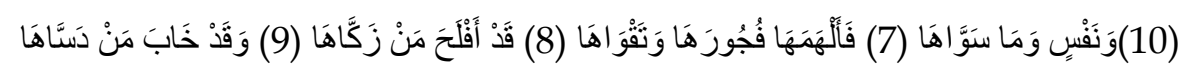

And [by] the soul and He who proportioned it (7), And inspired it [with discernment of] its wickedness and its righteousness (8), He has succeeded who purifies it (9), And he has failed who instills it [with corruption] (10) (QS. Ash-Shams, 91: 7-10)

Humans are definitely not born with an evil character. There is a power in their ontological structure that pushes them towards goodness. This power leads them back to their original state, to their fitrah, whenever they divert from the bondage of their ultimate goals. In the idiom of philosophers, if there is a certain quality which is susceptible to forces which have no relation to it, there will then be tendencies to return to the basic fitrah. ${ }^{28}$

Referring to the meaning of fitrah in the aspect of language and also the verses of the Qur'an, it can be concluded that fitrah is: "The elements, systems, and work procedures created by Allah in creatures from the beginning of creation until they become innate." Human basic fitrah is "innate".

That Humans walk using their feet is fitrah in the jasadiyah

${ }^{27}$ HR. Ahmad and Dâramî, "Al-Hadits an-Nabawi Wa 'Ilm an-Nafs (Mesir: Dâr Asy-Syurûq, Tt), Tjm, Hedi Fajar," in The Ultimate Psychology: Psikologi Sempurna Ala Nabi SAW, ed. by Muhammad Utsman Najati (Bandung: Pustaka Hidayah, 2008).

28 Sayyid Mujtaba Musawi Lari, Ethics and Spiritual Growth (Islamic Republic of Iran: Foundation of Islamic Cultural Propagation in the World. 1997), Tjm. Ahsin Mohammad \& Ruswan Dallyono, Mulia Di Mata Tuhan: Meraih Kesempurnaan Spiritual (Bandung: Pustaka Hidayah: Bandung: Pustaka Hidayah, 2006). 
element. That humans draw conclusions based on certain premises is called intellectual fitrah. Humans feel happy when they get pleasure and feel sad when they experience distress. They are attracted to the opposite sex. They love children and are attracted to property. All of which represent fitrah as a creature that Allah created. The understanding related to the fitrah based on the Qur'an above is also very different from Western theories which consider the basic human fitrah to be neutral. The behaviorism psychology school assumes that humans are not categorized good or bad at the beginning of their birth. They are like a piece of white paper, while the environment plays a role in shaping their personality. Or, as said by Skenner (1953): "Humans are just a variety of reflex movements. Religion and behavior can be explained according to environmental factors." 29

Islam basically also shows that the environment is very influential in the development of fitrah, but that does not mean that humans are servants to the environment like the opinion of the behaviorism school. The environment plays an important role in shaping a person's behavior, but the Qur'an does not state the environment as the only factor.

\section{Nafs}

In general, the nafs in the discourse of humans refers to the human side that has good and bad potential (faalhamaha fujūraha wa taqwäha). The Qur'an emphasizes that the nafs can be both positive and negative. ${ }^{30}$ In essence, human positive potential is stronger than the negative one, but the negative attraction seems stronger. ${ }^{31}$ The word nafs is a word that has many meanings (lafaż musytarak) and must be understood based on its usage. This is an important note for anyone who wants to understand Lafaż Musytarak in order to be able to understand the true meaning that is intended so as not to reduce the quality of interpretation, nor to just use one meaning in a variety of different conditions. Lafaż Musytarak is sometimes used and contains several meanings, but sometimes it also contains all the meanings it represents.

The word nafs in the Qur'ān has the following meanings:

a. Soul or something that has existence and essence. Nafs in this sense consists of body and spirit, as found in QS. $5: 45 ; 32: 13 ; 2: 286$ and 231.

${ }^{29}$ Hasan Langgulung, Manusia dan Pendidikan: Suatu Analisis Psikologis, Filsafat dan Pendidikan. (Jakarta: Pustaka Alhusna Baru. 2004), 67

30 Munawar Rahmat, "Manusia Menurut Al-Quran Cenderung Mempertuhankan Hawa Nafsunya," Taklim - Jurnal Pendidikan Agama Islam 10, no. 2 (2012): 105-22.

31 Abdul Rahman Shaleh, Psikologi: Suatu Pengantar dalam Perspektif Islam. (Jakarta: Kencana. 2008), 62. Idi Warsah, "Forgiveness Viewed from Positive Psychology and Islam," Islamic Guidance and Counseling Journal 3, no. 2 (2020): 108-21. 
, Vol. 25, No. 02 Juli - Desember 2020

b. Ruh that triggers life. When ruh is lost from the body, death will come. Nafs in this sense is seen in QS. 9: 55 and 6: 93.

c. Self or a place where the heart resides. Nafs in this sense is always attributed to Allah and also to humans. This is seen in QS. 3:28; 4: 79 and 5: 116 .

d. A trait of human beings that has a tendency towards good and evil. This can be found in QS. 5:30 and 12:18.

e. The nature of humans in the form of feelings and senses that they leave aside when they are asleep. This is seen in QS. 39: 42.

f. A compound language style which means "to each other". When it is said, "Respect yourself". Then, what is meant is a suggestion to respect each other. This can be found in QS. 2: 54 and 85.

g. A general word that applies to men, women, and also people (tribes). This can be found in QS. 30: 21; 16:72; and 9: 128.

h. A certain person (Adam). This is seen in QS. 4: $1^{32}$

The above meanings are implied in the Qur'an. However, if we observe and make further analyses, those meanings of nafs can be summarized into two main meanings: First, one general word overarches everything that exists in humans. The opposite of this word in the Qur'an is al-Afäq (universe). Second, a specific word means soul and spirit. The opposite of this word in the Qur'an is physical or land. ${ }^{33}$

Robert Frager, a psychologist as well as a Sufi, perceives that the word nafs is sometimes translated as soul or ego. Other meanings of nafs are breath and essence. However, in Arabic the word nafs is more often represented as 'self', as in the general language style which means 'myself', 'you', and the like. ${ }^{34}$ On the other hand, Robert Frager also argues that the nafs is a process produced by interactions between spirit and body, not a static psychological structure. There is absolutely nothing wrong with spirit and body. However, the process of both can be distorted. ${ }^{35}$

Most Sufis use the term nafs to refer to bad qualities and tendencies, so that at its lowest level, the nafs can lead to astray. This understanding was confirmed by al-Quraisi as cited in Quraish Shihab. He stated, "Nafs in the sense of Sufis is something that gives birth to despicable qualities and bad behavior." This opinion shows that there is a difference in understanding between the Qur'ān and the Sufis' terminology about nafs. This understanding is the same as the explanation of "the Big Indonesian Dictionary", which explains the

32 Muhammad Izzuddin Taufiq, At-Ta'shil Al-Islami Lil Dirasât an-Nafsiyah (Kairo: Darus Salam. Tt), Tjm. Sari Narulita, Panduan Lengkap \& Praktis Psikologi Islam (Jakarta: Gema Insani Press, 2006).

${ }^{33}$ Muhammad Izzuddin Taufiq.... 73

${ }^{34}$ Sudirman Tebba, Ruh.....16

${ }^{35}$ Sudirman Tebba, Ruh..... 17 
meaning of the word lust, as "a strong impulse to do less good". Therefore, humans are required to maintain the purity of their nafs and not pollute it, as described in QS. 91: 9-10.

The above verses are understood by most scholars that the positive potential has more influence than the negative potential. This is not only seen because humans already have the potential for religious nature alone, but also this tendency towards goodness is seen in several verses of the Qur'ān, including in the QS. 2: 266: The nafs gets a reward from what it works for and gets the torment for what it endeavors also.

The word kasabat contained in the verse indicates a good effort so that it is appreciated, which according to Quraish Shihab is patron in Arabic to describe things that are done easily; while iktasabat is a patron to show difficult things. According to Muhammad Abduh, this implies that the nafs is actually easier to do good than evil, and further implies that Allah created humans to do good. ${ }^{36}$

In another verse it is also detected that nafs is defined as a container. QS. Ar-Ra'd 13:11 states, "Allah does not change people until they change what is in their nafs". What is in the nafs this context is "strong ideas and desires." This means that the nafs accommodates both of these things, changing these two things is an absolute condition for change in the real world. The ideas and desires of a group of people can change the situation in society. Ideas or volition alone are not sufficient to make a difference. However, according to the Quraish Shihab, it is not only "ideas and wills" that are accommodated by the container of the nafs because there is also what is called conscience. This is what makes people regret making mistakes, feel guilty for their mistakes (although they themselves can cover up mistakes for various reasons). The signs of the existence of conscience in the human nafs are stated by the Qur'an in Surah al-Qiyamah 75: 14-15, "Even man will be a witness against himself even though they (verbally) make excuses."

The Qur'an further states that what is contained in the container of the nafs is not only an idea / knowledge that humans are aware of and their will and conscience, but that the nafs also accommodates hidden knowledge (which is no longer aware of) by its owner. In QS. Thaha 20: 7, it is stated, "If you harden your words, then (Allah knows because He also) will know what is secret and what is more hidden." 37

What is contained in the nafs can also appear in dreams, which the Qur'an generally divides into two main parts. First, it is called $r u^{\prime} y a$, second is called adhghaatsu ahläm. The first part is understood by the description / symbol of events that have been, are being, or will be experienced, and which have not / did not cross the dream mind. In the meantime, the second is born from human anxiety or their attention to 
, Vol. 25, No. 02 Juli - Desember 2020

something, and also things that are already in the subconscious. ${ }^{38}$

\section{Qalb}

Qalb, is the potential brought by the spirit. This potential flows into the essence of the human heart which is supernatural, subtle, and radiant. As you can feel, if a person has heart disease, the chest hurts and the heart is pounding. If someone is suffering from physical pain, it could mean that their liver is sick. However, if a person is psychologically injured, his chest hurts, his heart is injured, and anxiety arises. If someone's heart is hurt spiritually, it means that there is a spiritual disease, such as: shirk, nifaq, kufr, riya, wickedness, envy, ujub, and so on. Ali Abdul Halim Mahmud in Hamdani Bakran Adz-Dzakiey interpreted qalb as the tenderness of Rabbaniyah Ruhaniyah that resides in this heart. Qalb in this sense is human nature. It is the part that captures, absorbs, and has understanding in humans. It is charged with enforcing the law, and it is also the part that is rewarded and criticized. 39

On the other hand, Sa'id Hawwa provides an extension of qalb terminology. In his explanation, qalb refers to the following: "The subtle spiritual feeling related to the physical heart (material), and that subtle feeling is the essence of human being. It is the part of humans that knows and understands. It is the part that receives orders, criticism, sanctions, and prosecution. As previously mentioned, it has a relationship with the physical (material) heart. The human mind is confused about the location of such a relationship even though the relationship between the spiritual heart and the physical heart is the same as the relationship between character and body, between nature and nature, between the user of a tool and the tool itself, and between something occupying a place and a place itself. We explain this because we are cautious of two meanings. First, that it is related to mukasyafah science. Second, its realization requires the disclosure of the secrets of the spirit. By mentioning the word "heart" (qalb) we mean subtle feelings (latifah) and the objective is to mention only its properties and state, not its essence." 40

The word qalb as cited in Quraish Shihab is taken from the root word which means "turning over". It is because qalb often goes back and forth such as being oscilliated between very happy and very sad; and between to agree and to disagree. Qalb has the potential to be inconsistent. The Qur'ān also describes this. As regards the foregoing,

38 Hamdani Bakran Adz-Dzakiey, Psikologi Kenabian; Prophetic Psychology: Menghidupkan Potensi Dan Kepribadian Kenabian Dalam Diri (Yogyakarta: Beranda Publishing, 2007).

${ }^{39}$ Hamdani Bakran Adz-Dzakiey, Psikologi Kenabian..... 235

40 Sa'id Hawwa, Jalan Ruhani, Tjm. Khairul Rafie Dan Ibnu Thoha Ali (Bandung:

Mizan, 1998). 
there are four Qur'anic verses which contain the word qalb; 1). QS. AlHujurat 49: 7: "He (Allah) created faith and adorned it on your heart." 2). QS. Al-Hadid 57:27: "We make in the hearts of those who follow him (Isa.), compassion and mercy." 3). QS. Qaf 50: 37: "Surely in that there is a warning for those who have qalb or use hearing while he is watching the witnesses." 4). QS. A1-Imran 3: 151: "We will put into the hearts of those who disbelieve fear."41

From the verses above, it seems that qalb is a container of teaching, compassion, fear, and faith. The contents of qalb which are described by the above verses (and also in other verses) implicitly emphasize that qalb holds things which the owner is aware of. This is one of the proofs that 'qalb' and 'nafs' are different. As previously stated, the nafs also accommodates what is unconscious and or something that has been forgotten. From this, it can be understood that what to be accounted for is only the contents of the qalb, but not the contents of the nafs. As in QS. Al-Baqarah 2: 225, "Allah holds you accountable regarding what your qalb does." In its condition as a box / container, then of course it can be filled and / or its contents taken, as described in QS. Al-Hijr 15:47 "We revoke jealousy in their qalb, so that they all feel like brothers." Conversely, the qalb can also be filled with faith, or faith can be removed. For example, "... not yet having faith in their qalb" (QS. Al-Hujurāt 49: 14), even the Qur'ān describes a qalb that is closed or sealed (Surah A1-Baqarah 2: 7) . So, it is natural that the Qur'an states that there are keys to the closing of the qalb (QS. Muhammad. 47: 7).42

In addition, the qalb container can be enlarged / widened or reduced / narrowed. It is enlarged with good deeds such as: "They are whose hearts are expanded to accommodate taqwa" (Surah Al-Hujurāt. 49: 3), "Have we not expanded your chest?" (Surah Al-Insyirāh. 94: 1), "Whom Allah wants him to go astray, He makes his chest (heart) narrow again astray" (Surah A1-An'am. 6: 125). The word chest in this verse is the place of the qalb, as confirmed in (Surah Al-Hājj. 22: 46) "Surely it is not blind eyes, but the qalb that is in the chest." Then there is also the word qalb in several verses also understood in the meaning of 'tool' as in Surah Al-A'raf. 7: 179: "They have a qalb but are not used to understand".

It can be understood that qalb in this context is defined as a spiritual meaning that is not visible to the eye except with the mind (mukasyafah). Qalb acts as a place to receive feelings of love, education, news, knowledge, faith, fear, sincerity, Islam, and piety.

\section{Ruh}

Mustafa Mahmud in Baihaqi reveals that the terms nafs and ruh 
are often used interchangeably. It is often stated, for example: "Someone has a rising spirit, or it is tortured or doubtful or anxious or difficult." Everything is as if it is not true. These are things of the nafs, but not ruh. ${ }^{43}$ The Qur'ān states that ruh is always attributed to Allah. Ruh is always high, noble, clean, and honorable. It is never mentioned that ruh is tormented, or followed by, or cleansed, or tainted. It is never mentioned that there is ruh coming out of the body or experiencing death. Indeed, it is the nafs that experiences death, not ruh. Allah states in Surah Ali Imran, 3: 8: "Every nafs experiences death". When humans experience sakaratul maut, what comes out is also nafs, but not ruh. This is confirmed by the words of Allah in Surah Al-An'am 6: 93.

It has been explained by Allah that some of the functions of His spirit's breath: "Then $\mathrm{He}$ (Allah) made his offspring (human descendants) from the despicable semen. Then, He (Allah) perfected and breathed on it a part of His spirit, and He made for you hearing, sight, and conscience" (Surah As-Sajadah 32: 8-9). However, if the nature of ruh is questioned, Quraish Shihab confidently answers it through the message of Allah as in QS. Al-Isra '17: 85.

\section{5. 'Aq1}

The word 'aql is not presented explicitly in the Qur'an unless it is demonstrated in the form of present and past verbs. In terms of language, the word 'aql originally means 'rope or barrier'. The Qur'an uses it for something that binds or prevents a person from falling into mistakes and sins. The Qur'an does not explain it explicitly, but it is explained based on the context of the verses that use the root 'aql. It can be understood that 'aql includes:

a. The power that has the function of interpreting and describing something is as in QS. A1-'Ankabut 29:43: "These are the parables We give to humans, but no one understands them except pious (knowledgeable) people". Humans have different powers. This is also implied in the verses that explain the events of the heavens and the earth, the alternation of day and night, and so on. Some are stated as proofs of the oneness of Allah for those who are wise (a1-Baqarah 2: 164), and there are also those who use the word "Li Ulil Al-baab" which represents the same meaning but contains a sharper meaning than just having knowledge or understanding.

b. Moral encouragement, as in QS. Al-An'am 6: 151 "... and do not approach vile deeds - visible or hidden - do not also kill the soul which is forbidden by Allah with the right cause, thus God revealed to you, may you have the moral urge to leave it."

c. Power which serves to take lessons from something. The meaning of this power is usually used for the word rusyd. This 
power combines the two powers previously described, so that it contains the power of understanding, the power to analyze and conclude, and the moral drive accompanied by maturity in thinking.

Hence, the word 'aql in the Qur'an is a representation of the three meanings mentioned above. It can be said that the power of thought alone does not reflect the true meaning of reason; it is a moral impetus to do good and avoid mistakes because there is reason to think and understand the problem. ${ }^{44}$ From this, it can be understood why the inhabitants of hell in the future say "If we hear and have reasons, then surely we are not among the inhabitants of hell" (Surah Al-Mulk 67: 10).

\section{Fu'ad}

The word fu'ad is commonly represented as a guideline for qalb. It is also often associated with 'aql (reason). In the Qur'annic term, the word fu'ad (af'idah as the plural form) is repeated 15 times. Therefore, almost similar to qalb, it is a gift from Allah for humans to be able to absorb and perceive information in the form of both real and abstract information; that happened in the past, present, and future. However, qalb is a kind of container as well as a center of consciousness whose function is to accommodate all perceptions that humans realize, while fu'ad is a kind of clean spring of consciousness, the innermost human conscience. 45

$F u^{\prime} a d$ is the deepest feeling of the heart which is often referred to as the conscience (the light of the heart's eyes), and it functions as a memory store. It is very sensitive to movement or impulses and feels the consequences. If the heart is kufr, then fu'ad joins $k u f r$ and experiences suffering. When the heart is churned by danger, or the heart is touched by mental torment, fu'ad feels like it is on fire. When the heart is calm, fu'ad is also peaceful and happy. One of the advantages of fu'ad compared to the heart is that fu'ad in any situation cannot lie. He cannot betray the testimony of what the heart reflects and what the ego does. Various feelings experienced by fu'ad are stated in several verses of the Qur'an as follows: (1) Fu'ad can become restless (QS. Al-Qasas: 10); (2) with the revelation of the Qur'an to Prophet, Fuad Nabi became firm (Surah al-Furqan: 32); (3) Fu'ad could not lie (Surah An-Najm: 11); (4) The wrongdoer has an empty heart [confused] (QS. Ibrahim: 43); (5) for people of polytheism, fu'ad and their views are

44 Prima Aswirna and Reza Fahmi, "Al-Qur'an and Human Mind: The Facts of Science Development," Walisongo: Jurnal Penelitian Sosial Keagamaan 23, no. 2 (2015): 437. 
, Vol. 25, No. 02 Juli - Desember 2020

reversed or shaken (Surah al-An'am: 110). ${ }^{46}$

If the entire personality structure is still within the scope of the fitrah 'frame' as described above, then the personality will not lose its humanity. ${ }^{47}$ On the other hand, if human mental abilities exceed fitrah, then they will come out of their human nature, in both negative and positive senses. In a positive sense, the human has lost Insaniyah so that he resembles an "angel" while in the negative sense, the human has lost his spiritual power so that he falls into the "devil" personality. Schematically, the hierarchical structure of humans that will shape their personality according to the concept of the Qur'an can be seen in Figure 1.48

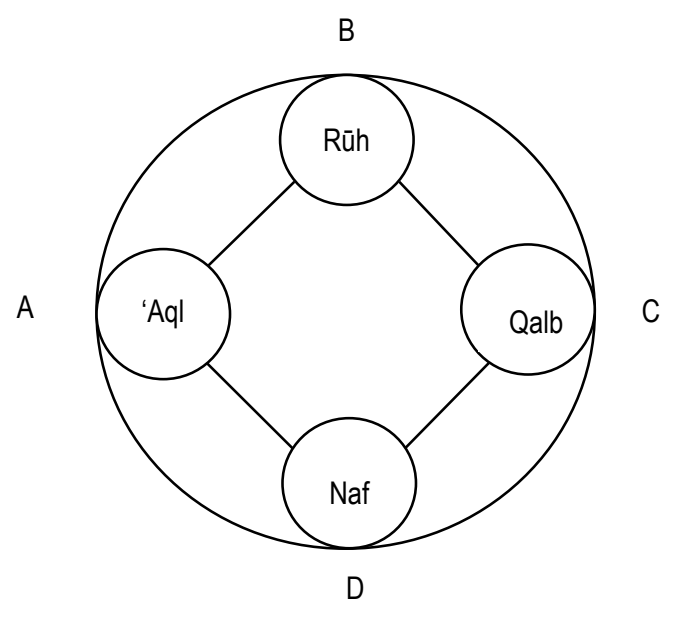

Figure 1: Dimensional Structure of Human Soul

The $A B C D$ framework is a fitrah framework that covers the dimensions of the nafs so as not to leave the human frame. In Figure 2, it is clearly illustrated the hierarchy of the highest power of rūh and lowest power of nafs. This is the human structure according to Baharuddin's understanding of the verses of the Qur'ān. ${ }^{49}$

46 Jalaluddin, Psikologi Agama, Cet-5 (Jakarta: Raja Grafindo Persada, 2001).

47 Idi Warsah and Muhamad Uyun, "Kepribadian Pendidik: Telaah Psikologi Islami," Psikis : Jurnal Psikologi Islami 5, no. 1 (2019): 62-73.

48 Yadi Purwanto, Epistemologi Psikologi Islami: Dialektika Pendahuluan Psikologi Barat Dan Psikologi Islami (Bandung: Refika Aditama, 2007).

49 Baharuddin, Paradigma Psikologi Islami (Yogyakarta: Pustaka Pelajar, 2004), 


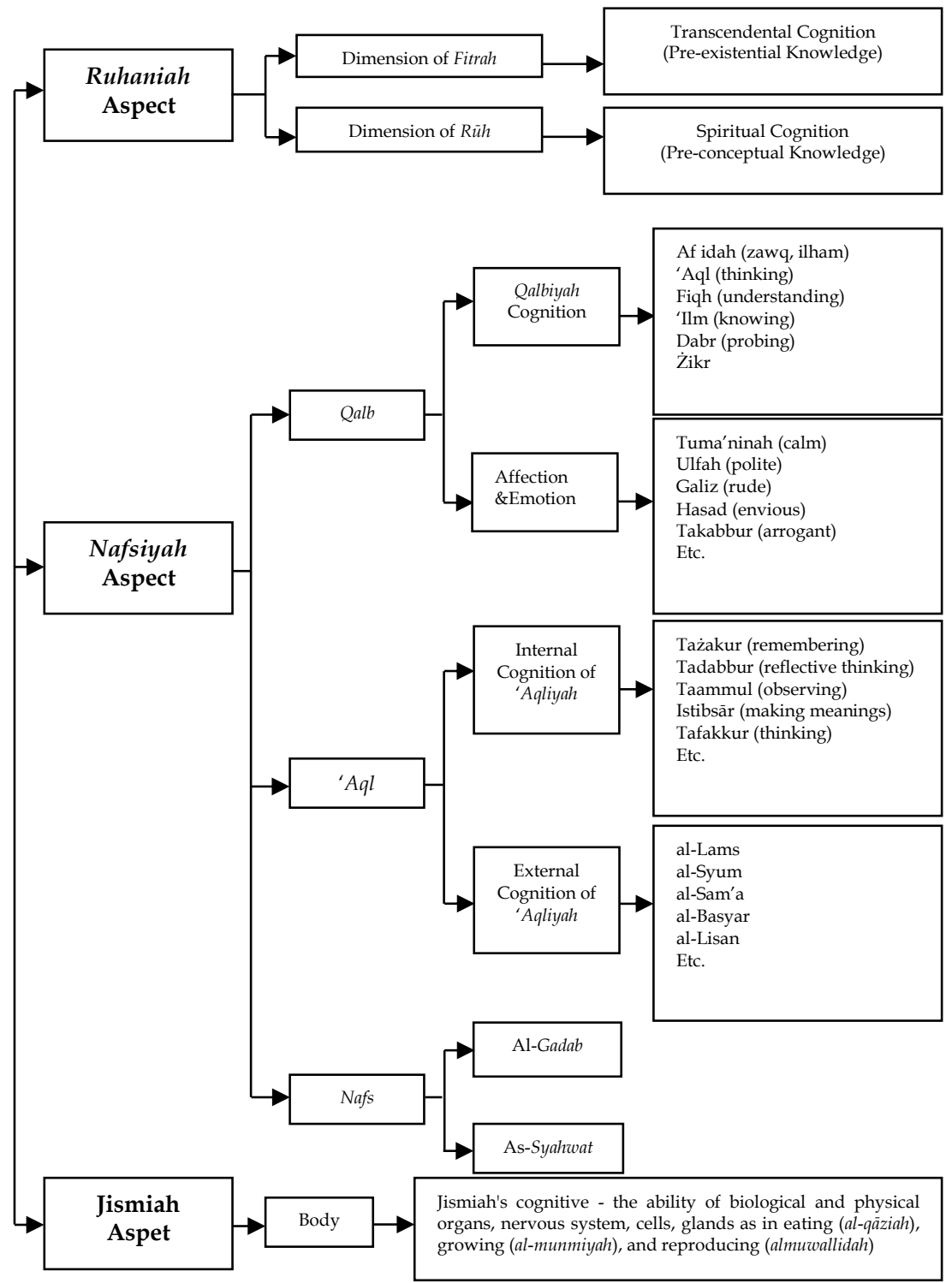

The Structure of Human Power Based on Understanding of the Qur'ān by Baharuddin

\section{Conclusion}

The discourse about humans in the perspective of psychological theories is seen from the aspects of physical condition (organo biology), psycho-education and environment (sociocultural). The essence related to spirituality is only mapped in the element of human subjective perceptions. However, there is a different perspective on human discourse grounded in the Qur'an. The Qur'ann explains that basically the human spiritual element is holy and good because it is created from a good origin as well. The divine spirit was breathed by Allah into the human body, and with this divine spirit, 
humans were able to connect with Allah. In this case, it is clear that the connection between humans and Allah is in a spiritual relationship which is physically manifested in the form of worship. In this study in terms the human psychological dimensions in the Qur'anic perspective, it can be concluded that humans consist of physical, psychological, and spiritual dimensions. Humans are born to have the nature of "Good Active" and innate elements, including the soul itself and its support for the outside world which is active and responsive so that these two elements will shape human behavior. Even though the outside world does not totally shape human beings like the goals of educators, the inborn potencies will not develop automatically without being accompanied by a good and conducive environment and an effective educational process, given that human nature is responsive. 


\section{REFERENCES}

Abdullah, Dudung, "Konsep Manusia dalam Al-Qur'an (Telaah Kritis Tentang Makna dan Eksistensi)." Al Daulah: Jurnal Hukum Pidana dan Ketatanegaraan 6, no. 2 (2017): 331-44.

Adz-Dzakiey, Hamdani Bakran, Psikologi Kenabian; Prophetic Psychology: Menghidupkan Potensi dan Kepribadian Kenabian dalam Diri. Yogyakarta: Beranda Publishing, 2007.

Ahmad, HR., and Dâramî, "Al-Hadits an-Nabawi Wa 'Ilm an-Nafs (Mesir:

Dâr Asy-Syurûq, Tt), Tjm, Hedi Fajar." in The Ultimate Psychology: Psikologi Sempurna Ala Nabi SAW, ed. by Muhammad Utsman Najati. Bandung: Pustaka Hidayah, 2008.

Al-Ghazāli, Ihya' Ulum Ad-Din, Jilid. III. Surabaya: Dar an-Nasyr alMishriyyah.

Aswirna, Prima, and Reza Fahmi, "Al-Qur' an and Human Mind: The Facts of Science Development." Walisongo: Jurnal Penelitian Sosial Keagamaan 23, no. 2 (2015): 437.

Baihaqi, MIF, Psikologi Pertumbuhan: Kepribadian Sehat Untuk Mengembangkan Optimisme. Bandung: Remaja Rosdakarya, 2008.

Bunch, Aaron, "Beyond Tabula Rasa." Argumentation and Advocacy 30, no. 3 (1994): 174-81.

Dayyab, Abdul Hamid, and Ahmad Qarqauz, Penomena Temuan Medis: Dalam Kajian Al-Qur'ān. Jakarta: Restu Ilahi, 2004.

El-Ramady, Hassan, Tarek Alshaal, Alaa El-Dein Omara, Tamer Elsakhawy, and Zakaria Abdalla, "Soils and Human Creation in the Holy Quran: From Point of View of Soil Science," Environment, Biodiversity and Soil Security (2019): 1-9.

Freire, Teresa, "Leisure and Positive Psychology : Contributions to Optimal Human Functioning." The Journal of Positive Psychology (2018): 1-4.

Hawwa, Sa'id, Jalan Ruhani, Tjm. Khairul Rafie Dan Ibnu Thoha Ali. Bandung: Mizan, 1998.

Hidayat, Komaruddin, Agama Di Tengah Kemelut. Jakarta: Mediacita, 2001. Hitami, Munzir, Revolusi Sejarah Manusia: Peran Rasul Sebagai Agen Perubahan. Yogyakarta: LkiS, 2009.

Jalaluddin, Psikologi Agama, Cet-5. Jakarta: RajaGrafindo Persada, 2001.

Khosravi, Hamed, "Geopolitics of Tabula Rasa: Persian Garden and the Idea of City." Journal of Architecture and Urbanism 38, no. 1 (2014): 39-53.

Kodir, Abdul, and Wawan Sonjaya, "Human Nature Based on Al- Qur'an as the Basic of Education Development." 1, no. 3 (2015): 1-26.

Lari, Sayyid Mujtaba Musawi, Ethics and Spiritual Growth (Islamic Republic of Iran: Foundation of Islamic Cultural Propagation in the World. 1997), Tjm. Ahsin Mohammad \& Ruswan Dallyono, Mulia Di Mata Tuhan: Meraih Kesempurnaan Spiritual. Bandung: Pustaka Hidayah, 2006.

Muthahhari, Murtadha, Perspektif Al-Qur'ān Tentang Manusia Dan Agama. Bandung: Mizan, 1992.

Nurdin, Roswati, "Manusia dalam Sorotan Al-Qur'an (Suatu Tinjauan Tafsir 
Maudhui)." Tahkim 9, no. 1 (2013): 155-71.

Purwanto, Ngalim, Psikologi Pendidikan. Bandung: Remaja Rosdakarya, 1999.

Purwanto, Yadi, Epistemologi Psikologi Islami: Dialektika Pendahuluan Psikologi

Barat Dan Psikologi Islami. Bandung: Refika Aditama, 2007.

Rahmat, Munawar, "Manusia Menurut Al-Quran Cenderung Mempertuhankan Hawa Nafsunya." Taklim - Jurnal Pendidikan Agama Islam 10, no. 2 (2012): 105-22.

Riker, John H., "What Do Humans Need to Be Human? Self Psychology and the Problem of Social Justice." International Journal of Psychoanalytic Self Psychology 10, no. 3 (2015): 192-204.

Rowland, Robert C., "Tabula Rasa: The Relevance of Debate to Argumentation Theory." Argumentation and Advocacy 21, no. 2 (1984): 7688.

Sangkan, Abu, Berguru Kepada Allah, Cet. X. Jakarta: Yayasan Shalat Khusu', 2008.

Syah, Muhibbin, Psikologi Pendidikan Dengan Pendekatan Baru. Bandung: Remaja Rosdakarya, 2008.

Syihab, M. Quraish, Membumikan Al-Qur'ān, Edisi Baru. Bandung: Mizan, 2007.

Syihab, M. Quraish, Tafsir Al-Misbah: Pesan, Kesan Dan Keserasian Al-Qur'ān, V. Jakarta: Lentera Hati, 2006), XI.

Syihab, M. Quraish, Wawasan Al-Qur'ān: Tafsir Tematik Atas Pelbagai Persoalan Umat, Edisi Baru. Bandung: Mizan, 2007.

Taufiq, Muhammad Izzuddin, At-Ta'shil Al-Islami Lil Dirasât an-Nafsiyah (Kairo: Darus Salam. Tt), Tjm. Sari Narulita, Panduan Lengkap \& Praktis Psikologi Islam. Jakarta: Gema Insani Press, 2006.

Togashi, Koichi, and Amanda Kottler, "The Many Faces of Twinship: From the Psychology of the Self to the Psychology of Being Human." International Journal of Psychoanalytic Self Psychology 7, no. 3 (2012): 331351.

Warsah, Idi, "Forgiveness Viewed from Positive Psychology and Islam." Islamic Guidance and Counseling Journal 3, no. 2 (2020): 108-121.

Warsah, Idi, "Interkoneksi Pemikiran Al-Ghazāli Dan Sigmund Freud Tentang Potensi Manusia." Kontekstualita: Jurnal Penelitian Sosial dan Keagamaan 33, no.1 (2017): 54-77.

Warsah, Idi, Yusron Masduki, Mirzon Daheri, and Ruly Morganna, "Muslim Minority in Yogyakarta: Between Social Relationship and Religious Motivation," Qudus International Journal of Islamic Studies 7, no. 2 (2019): 1-32.

Warsah, Idi, and Muhamad Uyun, "Kepribadian Pendidik: Telaah Psikologi Islami." Psikis : Jurnal Psikologi Islami 5, no. 1 (2019): 62-73.

Wiedermann, Jiří, "The Computational Limits to the Cognitive Power of the Neuroidal Tabula Rasa." Journal of Experimental \& Theoretical Artificial Intelligence 15, no. 3 (2016): 267-79. 